\title{
Neurological recovery after traumatic Cauda Equina syndrome due to glass fragments: An unusual case
}

\author{
Mehmet Şenoğlu, M.D., Ali Karadağ, M.D., Çağlar Türk, M.D., Füsun Demirçivi Özer, M.D.
}

Department of Neurosurgery, Health Sciences University, Tepecik Research and Training Hospital, İzmir-Turkey

\begin{abstract}
Penetrating spinal injuries with foreign bodies are exceedingly rare. To date, pathological problems due to glass fragments in the spinal canal have rarely been reported. In this report, the case presenting with a back laceration, leg pain, and leg weakness was found to have glass frag-ments in the spinal canal at the L2-L3 level by lumbar computed tomography and magnetic resonance imaging. After L2 total laminectomy and retrieval of the glass fragments, the dura was re-paired.The patient was discharged from the hospital after complete neurological recovery. In cases of spinal canal injuries due to foreign bodies, early operative decompression of the neural elements is the treatment of choice. Patients with Cauda Equina syndrome due to glass fragments have a good prognosis for functional recovery.
\end{abstract}

Keywords: Cauda Equina injury; cerebrospinal fluid leak, foreign body; operative; outcomes.

\section{INTRODUCTION}

Direct injuries of Cauda Equina fibers from foreign bodies are exceedingly rare. ${ }^{[l]}$ Penetrating injuries of the spine most commonly occur because of sharp objects or gunshot wounds. Penetrating spinal injuries secondary to glass are very rare; to date, only a few cases have been reported in English medical literature. ${ }^{[1]}$ We report a case of Cauda Equina syndrome as a result of penetrating trauma due to glass, after the patient fell on a glass table.

\section{CASE REPORT}

A 26-year-old female fell backward on a glass table, which shattered. Glass shards penetrated her back, and she was brought to our emergency room. She was complaining of right leg pain and weakness. On physical examination, an arterial blood pressure of $120 / 75 \mathrm{mmHg}$, a pulse rate of $80 /$ $\mathrm{min}$, a respiratory rate of $20 \mathrm{breaths} / \mathrm{min}$, and an axillary temperature of $36.2^{\circ} \mathrm{C}$. She had a Glasgow Coma Scale of I5. Physical examination revealed a linear, $4-\mathrm{cm}$ laceration in the left paraspinal lumbar area with minimal external bleeding.
There were small pieces of glass fragments on the skin surface. Neurological examination demonstrated right lower extremity paresis and hypoesthesia. By Lovett scoring, ${ }^{[2]}$ motor strength was 2/5 for plantar flexion and 2/5 for dorsiflexion of the right ankle. The plantar response babinski reflex was detected bilaterally normal. Rectal sphincter muscle tone was normal. Urogenital examination result was normal. Other physical findings were also normal. Routine laboratory test results were all normal.

Computed tomography (CT) showed a hyperdense object compatible with a glass fragment entering the spinal canal between the spinous processes of L2 and L3 on sagittal images (Fig. I). In the spinal canal, under the L2 lamina, several small hyperdense objects were seen, along with hypodense areas (air). On axial slices, a fragment of glass that had entered the spinal canal from the left was seen. The spinal canal at L2-L3 was narrowed by a radio-opaque foreign body, which entered from the left and pressed on the cauda fibers. In the left paraspinal muscle area, tissue density was increased because of subcutaneous edema and hematoma. A small amount of

Cite this article as: Şenoğlu M, Karadağ A, Türk Ç, Demirçivi Özer F. Neurological recovery after traumatic Cauda Equina syndrome due to glass fragments: An unusual case. Ulus Travma Acil Cerrahi Derg 2018;24:82-4

Address for correspondence: Mehmet Şenoğlu, M.D.

Sağılık Bilimleri Üniversitesi Tepecik Eğitim ve Araştırma Hastanesi, Nöroşirürji Kliniğ̈i, İzmir, Turkey.

Tel: +90 232 - 4696969 E-mail: mehmetsenoglu@hotmail.com

Ulus Travma Acil Cerrahi Derg 2018;24(I):82-84 DOI: 10.5505/tjtes.2017.40583 Submitted: 19.05.2017 Accepted: 21.08.2017

Copyright 2018 Turkish Association of Trauma and Emergency Surgery 
gas was seen in the spinal canal (Fig. Ia). On magnetic resonance imaging (MRI) at the L2-L3 level, in the right paraspinal subcutaneous and muscle tissues, a rod-shaped object of low-signal intensity was seen extending into the spinal canal to the L2-L3 level (Fig. Ib). Several hours after presenting to the emergency department, the patient was taken to the operating room. The spinal column and vertebral arches were exposed through a posterior incision from L2 to $L 3$. The wound was explored. Two glass fragments were removed from the paravertebral muscles, and then an L2 total laminectomy was performed. After the dura was opened, two small glass fragments and a $30 \times 20-\mathrm{mm}$ glass fragment, which was compressing the Cauda Equina, were removed (Fig. Ic). No intraoperative complications occurred, and after duraplasty, no signs of cerebrospinal liquid leak were observed. Postoperatively, the patient noticed that her leg pain had resolved while still in the recovery room. Within 24 hour postoperatively, neurological recovery was complete, with 5/5 plantar flexion and 5/5 dorsiflexion strength of the right ankle. At 2 days postoperatively, she was ambulating without support. Postoperative lumbar CT showed no foreign bodies in the spinal canal (Fig. Id).

\section{DISCUSSION}

Spinal injuries are most commonly due to falls, motor vehicles, and sports-related accidents. ${ }^{[1,3]}$ Penetrating injuries of the spinal canal are relatively rare compared to those caused by blunt trauma. Most are caused by bullets and knives; spinal injuries by glass fragments are extremely rare. ${ }^{[1,3,4]}$ Anamnesis, physical examination, and imaging techniques must be done for the right treatment option prior to the removal of the embedded object. If the foreign body is made of lead or copper, systemic toxicity may develop. In such cases, surgery is indicated even if neurological symptoms are absent. Urgent surgery to remove sharp foreign bodies in the spinal canal is indicated to prevent neurological deterioration, independent of the level of injury. ${ }^{[3,4]}$ Besides direct damage to nerves, other risks of foreign bodies in the spinal canal are cerebrospinal fluid fistula and infection. During closure of the dura, removal of hematoma, bone fragments, and foreign bodies is important to lower the risk of infectious complications. ${ }^{[4,5]}$

Neurological deficits related to direct injury are usually evident immediately after the trauma. Severe initial neurological deficits rarely improve after decompressive surgery. Delayed deficits may occur because of infection, granuloma formation, iron encrustation, or direct contact of the glass fragments with neural tissue..$^{[3,5]}$ Both plain radiographs and CT are fast and effective imaging modalities for demonstrating metallic and glass foreign bodies. CT can also show the trajectory of the injury. ${ }^{[4,5]} \mathrm{MRI}$ can also provide precise data about the location of glass fragments. ${ }^{[5]}$ In our case, CT scan demonstrated the glass fragment adjacent to lamina, and then the MRI showed that the glass fragment was located intradurally.

After spinal cord injuries, a variety of motor, sensory, and autonomic function loss below the level of lesion may occur. $^{[1,3]}$ In our patient, only a unilateral partial motor deficit was present. The prognosis for functional recovery is good in patients with Brown-Sequard or Cauda Equina syndrome.
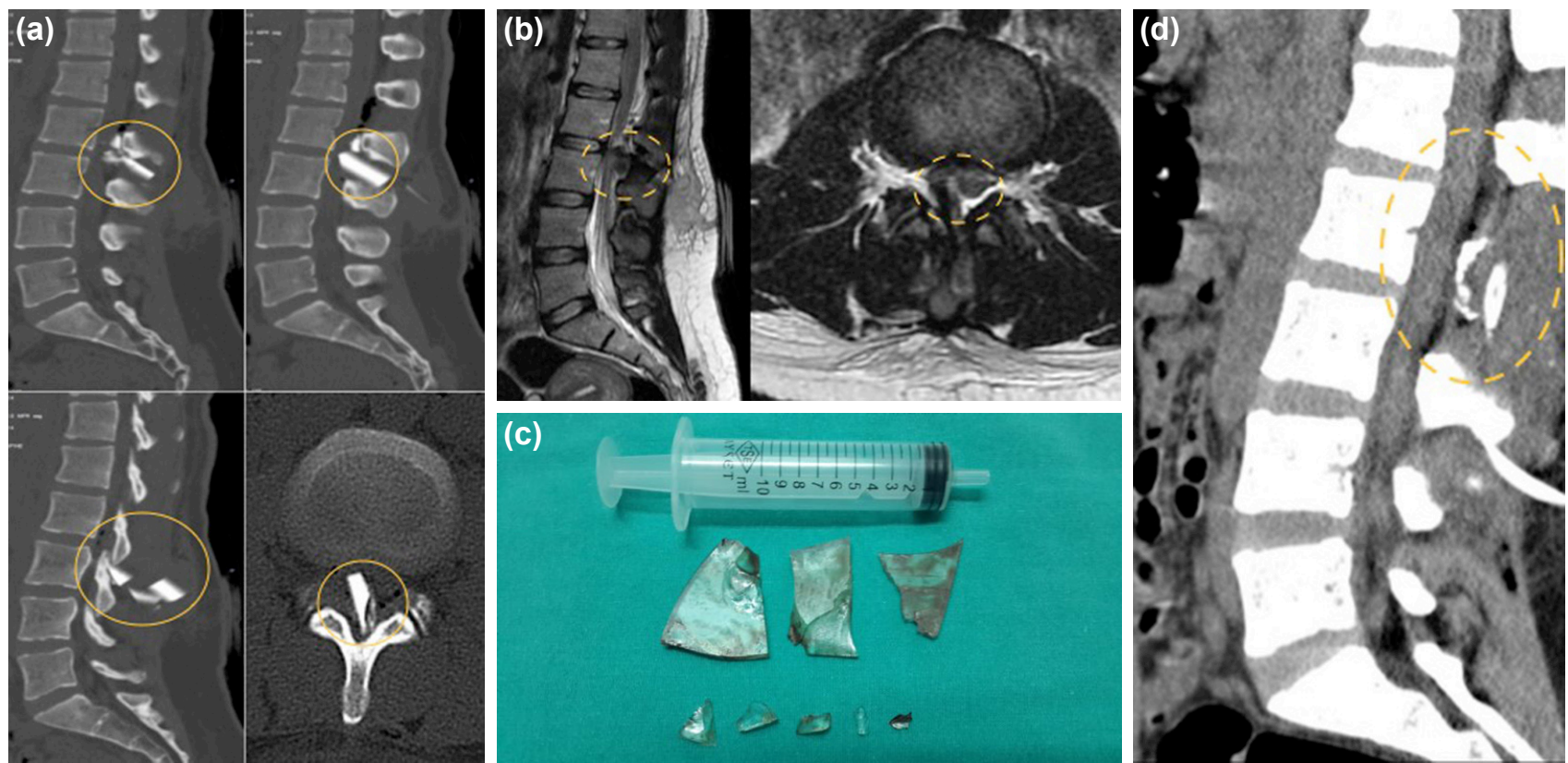

Figure 1. (a) Sagittal CT at L2-L3. A glass fragment from the broken table is seen intruding into the spinal canal. (b) T2-weighted sagittal MRI images show a hypointense object in the spinal canal. (c) Glass fragments from the broken table after removal from the spinal canal. (d) Postoperative lumbar CT. No foreign bodies are seen in the spinal canal (CT: Computed tomography; L: Lumbar; MRI: Magnetic resonance imaging). 
[1] Good functional recovery is related to rapid, aggressive decompressive surgery of the Cauda Equina region. ${ }^{[4,5]}$ Wide surgical exposure enables safe removal of intradural foreign bodies under direct visualization after the lamina is partially or totally removed. ${ }^{[3]}$ Failure to remove a retained foreign body from within the spinal canal may result in cerebrospinal fluid leak, osteomyelitis, meningitis, migration of the foreign body, and/or progressive neurological deficits. ${ }^{[4]}$

In summary, rapid imaging and aggressive operative management in cases of penetrating traumas to the spinal cord may improve the chances for rapid improvement and optimal long-term neurological outcome.

Conflict of interest: None declared.

\section{REFERENCES}

1. Baghai P, Sheptak PE. Penetrating spinal injury by a glass fragment: case report and review. Neurosurgery 1982;11:419-22. [CrossRef]

2. Dyck PJ, Boes CJ, Mulder D, Millikan C, Windebank AJ, Dyck PJ, et al. History of standard scoring, notation, and summation of neuromuscular signs. A current survey and recommendation. J Peripher Nerv Syst 2005;10:158-73. [CrossRef]

3. Opel DJ, Lundin DA, Stevenson KL, Klein EJ. Glass foreign body in the spinal canal of a child: case report and review of the literature. Pediatr Emerg Care 2004;20:468-72. [CrossRef]

4. Oertel MF, Kreitschmann-Andermahr I, Ryang YM, Gilsbach JM, Korinth MC. The awak-ened intraspinal glass shard. Acta Neurochir (Wien) 2009;151:99-101. [CrossRef]

5. Akcakaya MO, Aras Y, Yorukoglu AG, Ovalioglu C, Sencer A. Cervical intradural glass fragment: a rare cause of neuropathic pain. Turk Neurosurg 2012;22:667-70.

\section{OLGU SUNUMU - ÖZET}

\section{Cam parçacıkları nedeniyle oluşan travma kaynaklı Cauda Equina sendromunda tam nörolojik iyileşme: Olağandışı olgu \\ Dr. Mehmet Şenoğlu, Dr. Ali Karadağ, Dr. Çağlar Türk, Dr. Füsun Demirçivi Özer \\ Sağlık Bilimleri Üniversitesi Tepecik Eğitim ve Araştırma Hastanesi, Nöroşirürji Kliniği, İzmir}

Yabancı cisimlerle omurilik yaralanmaları oldukça nadirdir. Bununla beraber patolojik problemlere neden olan spinal kanalın içindeki cam parçacıkları çok nadir raporlanmıştır. Bu raporda, lomber manyetik rezonans görüntüleme ve bilgisayarlı tomografı kullanılarak sırtta laserasyon, bacakta ağrı ve güç kaybı ile gelen ve L2-L3 seviyesinde cam parçacıkları mevcut hasta sunuldu. L2 total laminektomi ve cam parçacıklarının tamamen çıkartılması sonrası dura tamir edildi. Takiplerde tam nörolojik iyileşme saptanan hasta taburcu edildi. Bu cam fragmanlarıla olan spinal yaralanmalarda nöral elemanların erken operatif dekompresyonu seçeneklerden biridir. Cam parçacıklarıyla ilişkili Cauda Equine sendromlu hasta, fonksiyonel olarak iyi bir prognoza kavuşmuştur.

Anahtar sözcükler: Beyin omurilik sıvısı sızıntısı; Cauda Equina yaralanması; operatif; sonuçlar; yabancı cisim.

Ulus Travma Acil Cerrahi Derg 20I8;24(I):82-84 doi: 10.5505/tjtes.2017.40583 